- the standard is very low. Meanwhile, until films are made to the requirements of teachers, really educational films are hard to get. The position of the sound-film is particularly difficult-facetious commentaries and lack of precise facts are obvious. Many teachers are turning from the film to other aids; of these the strip-film is the most important. In addition to the demonstration of class-room and background exhibitions, the need for making visual material available to the schools was stressed. Much useful material is available in museums, and teachers must be helped and guided in its use. The question of recording all exhibitions in booklet form is important. The Warburg Institute has done valuable work in this direction by means of photographs. Now the Army Bureau of Current Affairs, the Navy and many public bodies are arranging exhibitions, which contain material, facts and ideas of great educational use. Some central organization is needed to preserve this valuable work for educational purposes.

\section{Place of Psychology in the Sciences}

AdDressing a colloquium of the University of Manchester Branch of the Association of Scientific Workers on May 5, Prof. T. H. Pear explained why in psychology the traditional methods of science are sometimes inadequate. Science has sometimes been defined as measurement and sometimes as organized knowledge of facts, but not all facts can be measured. Moreover, if by facts be meant only events which are in principle open to observation by everyone who wishes to observe them, the psychologist has to study many phenomena, for example, mental images and colour experiences, which are not facts in this sense. Some would claim that they are therefore not amenable to the methods of science, but nevertheless they exist and are important; synæsthesia, for example. Physics has succeeded in maintaining a rigorous scientific method by ignoring certain difficult aspects of experience.

Prof. Pear said that there are few 'inner' inhibitions against analysing or manipulating inanimate matter ; more against studying the workings of the human body, and still more against intimate investigation of the mind. He urged the study of individuals side by side with the search for general laws. If this is not to be called science, scientific men should remember that in the case of human beings it may often be the more important study. $\mathrm{He}$ concluded by suggesting that the motives of the economist, the politician, of even the man of science, are subjects which interest the social psychologist.

\section{Light and Vision}

Aт a meeting of the Illuminating Engineering Society following the annual general meeting on May 11, Sir John Parsons gave an address on "Light and Vision". In his opening remarks Sir John recalled his presence at the inaugural dinner of the Society in 1909 , and the recognition of the founder of the Society, Mr. Leon Gaster, that its aims were not limited to physical problems, but involved physiological, psychological and æsthetic factors. At that time there was little guidance on lighting matters from the medical side, but engineers had themselves little data, and instruments for measuring illumination were primitive and cumbersome. The first paper read to the Society on glare in 1910 was given by himself, and the Society has since been preoccupied with this and similar problems involving vision. Sir John then discussed the relation between illumination and visual acuity, directing attention to the valuable work of Dr. Lythgoe and others and the development of the Illuminating Engineering Society's Code. Research has established the great importance of background and adequate contrast. The work of Dr. Stiles and others on glare (for which we have no actual physiological test), the effects of specular reflection from polished material and the inconvenience and occasional danger of harsh shadows-most difficult, however, to define with precision-were dealt with. Turning to the colour of light Sir John expressed the view that there is no evidence that artificial sources furnishing so-called 'white light' cause any harmful effects. The injurious effects of ultra-violet light in everyday life have been grossly exaggerated and the craze for 'daylight' lamps has been unwarranted.

Much of the later part of the address was devoted to vision at low illuminations, the peculiar appearance of colours in weak light and the conditions determining the perception of objects at the very low illuminations which are now experienced in the streets in war-time. Reference was made to the work of the Departmental Committee on Lighting in Factories and Workshops, and to the fact that legislation on factory lighting, recommended before the War of 1914-18, has only become a fact during the present War. Sir John referred to the value of the Illumin. ating Engineering Society Code and the recent researches on this subject by $\mathrm{Mr}$. $\mathrm{H}$. C. Weston, in which an effort has been made to give a scientific background without greatly disturbing the present set of values, which have become standard. The fact that requirements for adequate lighting in factories had now been incorporated in the Factory Act should serve as a precedent for the future, when lighting conditions in schools, offices, etc., might likewise be defined and standardized. The recognition of the I.E.S. Code during the War has been largely due to the fact that it was ready when needed. Now, therefore, is the time to complete codes and specifications relating to other fields of lighting.

\section{Protection of Structures Against Lightning}

J. F. SHIPLey, in a paper read in London before the Institution of Electrical Engineers on May 6, points out that the British Standards Institution has recently issued recommendations on this subject which constitute the first authoritative general guidance made available to the public in Great Britain since the Report of the Lightning Rod Conference in 1881 and its amendment by the Lightning Research Committee in 1905 . These new recommendations have been adopted by the Ministry of Works and Planning as its first code of practice, the latter containing additional appendixes in which comment is made on some of the new features dealt with, and which the present paper amplifies to some extent. The paper is confined to problems connected with the protection of modern steel-framed and ferroconcrete structures. The need for protection is discussed and a rough attempt is made to assess the lightning risk attached to any structure in any part of the world. The zone of protection receives attention and the presence of metallic systems in the buildings is mentioned; while the needs of structures which are very vulnerable to lightning, and of others which present difficult problems, are discussed. The components of a lightning protective system, their 